ks. Henryk Sławiński

\title{
Głoszenie ewangelii nadziei w świetle adhortacji „Ecclesia in Europa"
}

Program duszpasterski 2004/2005 przebiega w Polsce pod hasłem Głosić ewangelię nadziei. Stanowi on wyraźne nawiązanie do ogłoszonej przez papieża Jana Pawła II w dniu 28 czerwca 2003 adhortacji apostolskiej Ecclesia in Europa, będącej podsumowaniem synodu biskupów poświęconego Europie. Pokaźna część tego dokumentu dotyczy głoszenia ewangelii nadziei. Przyjrzymy się temu zagadnieniu w odniesieniu do posługi przepowiadania słowa Bożego.

\section{Ewangelia nadziei i duchowy kryzys w Europie}

Termin „ewangelia” wywodzi się etymologicznie z języka greckiego, w którym oznacza „dobrą nowinę”. Dopiero od drugiego wieku przyjął się on na oznaczenie czterech ksiąg Nowego Testamentu, opowiadających o życiu, działalności i nauczaniu Jezusa Chrystusa, a także o Jego krzyżowej śmierci i zmartwychwstaniu ${ }^{1}$. Nadzieja zaś oznacza oczekiwanie na spełnienie Bożych obietnic i obok miłości i wiary należy do cnót teologalnych, które są ukierunkowane na Boga, godnego całkowitego zaufania i miłości². Nadzieja jest cechą, która w szczególny sposób odróżnia chrześcijanin od niewierzących (por. Tes 4, 13-16; Ef 2, 12). Mówienie o ewangelii nadziei brzmi niemal jak pleonazm, czyli zestawienie obok siebie bliskoznacznych słów, które mogłyby występować osobno, nie zakłócając treści zdania. W niewielu dokumentach Nauczycielskiego Urzędu Kościoła termin nadzieja występuje tak często, jak ma to miejsce w adhortacji apostolskiej Ecclesia in Europa Jana Pawła II. Znajdujemy go tam sto pięćdziesiąt trzy razy, w tym trzydzieści dziewięć razy w wyrażeniu „ewangelia nadziei”. Możemy zastanawiać się i pytać, dlaczego z taką emfazą papież mówi

${ }^{1}$ Por. G. O'Collins, E. G. Farrugia, Leksykon pojęć teologicznych i kościelnych z indeksem angielsko-polskim, Kraków 2002, s. 89.

${ }^{2}$ Por. G. O'Collins, E. G. Farrugia, Leksykon pojęć..., dz. cyt., s. 195; 54. 
o ewangelii nadziei w kontekście dokumentu podsumowującego synod biskupów z roku 1999 poświęcony staremu kontynentowi. Odpowiedzi można dopatrzyć się w analizie duchowego stanu Europy.

Europa w dużej mierze żyje bez świadomości obecności Boga, a nawet w negacji Jego istnienia, tak teoretycznej, jak i praktycznej. Fascynacja możliwościami człowieka, w myśl humanistycznego ateizmu, doprowadziła do stwierdzenia, że Bóg nie jest potrzebny; człowiek wystarczy sam sobie (podobno na Titanicu umieszczony był zuchwały napis: „Nawet sam Bóg nie zdoła go zatopić”). Wielu sytych Europejczyków żyje tak, jakby Bóg nie istniał. Kult chwili, hedonizm i konsumpcyjny styl życia zacierają pamięć3. Utrata zaś pamięci rodzi u wielu wrażenie, że żyją bez duchowego zaplecza, niczym spadkobiercy, którzy roztrwonili dziedzictwo pozostawione im przez historię ${ }^{4}$. Konsekwencją utraty chrześcijańskiej pamięci jest powolna utrata nadziei i lęk przed przyszłością. „Bardziej boimy się przyszłości, niż jej pragniemy" - pisze Jan Paweł II. Miejsce chrześcijańskiej nadziei zajmuje złudzenie, że można osiągnąć szczęście natury hedonistycznej, jakiego dostarcza konsumpcjonizm, albo też szczęście urojone, oferowane przez narkotyki ${ }^{6}$. Miejsce wiary opartej na historii zbawienia zajmuje często fascynacja enigmatycznymi wierzeniami, w których nie ma miejsca dla Boga, jak np. buddyzm czy astrologia. Odrzucenie zaś wiary w istnienie Boga i zredukowanie obszaru życia tylko do wymiaru doczesnego jest przyczyną wszelkiego pesymistycznego patrzenia na całą rzeczywistość. Tak zredukowany świat jawi się jako obszar, w którym człowiek cierpi, jest nieszczęśliwy i zagubiony. Wielu nauczycieli duchowych jest gotowych zastosować swoją terapię dla uzdrowienia Europy tracącej chrześcijańską pamięć. Stąd jesteśmy świadkami działalności sekt poszukujących wciąż nowych adeptów.

Istnieje w człowieku przestrzeń do zagospodarowania. Człowiek ze swej natury pragnie nie tylko wiedzieć, ale i wierzyć, dlatego jest zawsze potencjalnym adresatem ewangelii. Bez niej pozostałby niespokojny i narażony

${ }^{3}$ Por. G. DanneEls, Jak ewangelizować “zsekularyzowana” Europę?, „Orientacje. Biuletyn formacyjny Wspólnot Życia Chrześcijańskiego” 4/14 (1992), s. 1-3 [1-20].

${ }^{4}$ Por. JAN PAwEŁ II, adhortacja apostolska Ecclesia in Europa (28 czerwca 2003), 7 (dalej: EE). W popularnym wykładzie historii filozofii Jostein Gaarder (Świat Zofii. Cudowna podróż w głą historii filozofii, Warszawa 1995, s. 182) napisał dobitnie: „Wychodzimy ze starożytności. Od czasów pierwszych greckich filozofów upłynęło prawie tysiąc lat. Przed nami chrześcijańskie średniowiecze. Ono tez trwało około tysiąca lat. Niemiecki poeta Goethe powiedział kiedyś, że ten, «komu trzy tysiące lat nie mówią nic, niech w ciemności niewiedzy żyje z dnia na dzień». Nie chcę, byś Ty znalazła się wśród takich ludzi. Robię, co mogę, byś poznała swe historyczne korzenie. Tylko w ten sposób możesz stać się człowiekiem. Tylko w ten sposób będziesz czymś więcej niż tylko nagą małpą. Tylko w ten sposób unikniesz zawieszenia w próżni”.

${ }^{5}$ EE 8.

${ }^{6}$ Por. EE 10. 
na rozpacz, albowiem swoim wysiłkiem nie jest w stanie nadać sensu historii i jej kolejom ${ }^{7}$. Potrzebuje więc ewangelii. Potrzebuje ewangelii nadziei.

\section{Ewangelia nadziei i nasze przepowiadanie}

Kościół ma ewangelię nadziei. Jest jej depozytariuszem. „Kościół ma do zaofiarowania Europie najcenniejsze dobro, jakiego nikt inny nie może jej dać: jest to wiara w Jezusa Chrystusa, źródło nadziei, która nie zawodzi [...]. Tak, po dwudziestu wiekach, Kościół ma do ofiarowania na początku trzeciego tysiąclecia to samo orędzie, które stanowi jego jedyne bogactwo: Jezus Chrystus jest Panem; w Nim i tylko w Nim jest zbawienie (por. Dz 4, 12). Źródłem nadziei dla Europy i dla całego świata jest Chrystus, «Kościół zaś jest jakby kanałem przenoszącym i rozprzestrzeniającym falę łaski, tryskającej z przebitego Serca Odkupiciela»" ". Na fundamencie tego wyznania wiary rodzi się w naszych sercach i na naszych ustach „,radosne [...] wyznanie nadziei: Ty, o Panie zmartwychwstały i żywy, jesteś wiecznie nową nadzieją Kościoła i ludzkości; Ty jesteś jedyną i prawdziwą nadzieją człowieka i historii; Ty jesteś «pośród nas nadzieją chwały» (por. Kol 1, 27) w tym życiu i po śmierci. W Tobie i z Tobą możemy dotrzeć do prawdy, nasze życie ma sens, wspólnota jest możliwa, a różnorodność może stać się bogactwem. W Tobie i z Tobą moc Królestwa działa w historii i pomaga w budowie ludzkiej społeczności, a miłość nadaje wysiłkom ludzkości nieprzemijającą wartość. Z Tobą i w Tobie ból może stać się drogą zbawienia, życie zwycięży śmierć, a stworzenie dostąpi udziału w chwale synów Bożych" 9.

Kościół ma do zaoferowania mieszkańcom Europy i świata radosne orędzie, że Jezus Chrystus jest jedynym, niezbędnym pośrednikiem zbawienia i samym źródłem zbawienia. Tylko w Nim człowiek i ludzkość mogą urzeczywistnić się w pełni, albowiem „nie dano ludziom pod niebem żadnego innego imienia, w którym moglibyśmy być zbawieni” (Dz 4, 12) ${ }^{10}$. Dlatego Jezus Chrystus jest ewangelią nadziei, a Kościół - jej depozytariuszem. Wraz z nią otrzymał obowiązek głoszenia jej i dawania o niej świadectwa na co dzieńn ${ }^{11}$. Realizacja tego obowiązku jest właściwym powołaniem Kościoła. Kościół jest dla ewangelizacji. Nie może więc nie głosić słowa Bożego. Głoszenie Jezusa, które jest ewangelią nadziei, jest chlubą Kościoła i racją jego istnienia. Apokalipsa św. Jana wyraża tę prawdę w nakazie: „Idź, weź księgę otwartą w ręce anioła stojącego na morzu

\footnotetext{
${ }^{7}$ Por. EE 44.

${ }^{8} \mathrm{EE} 18$.

${ }^{9} \mathrm{EE} 18$.

${ }^{10}$ Por. EE 20.

${ }^{11}$ Por. EE 45.
} 
i na ziemi. [...] Weź i połknij ją" (Ap 10, 8-9). Jedynie przyswoiwszy sobie tę księgę do głębi, symbolizowany w osobie Jana Kościół może przekazywać ją innym ${ }^{12}$. „Napełnij serce swoje tym kosztownym nasieniem, a zobaczysz, że Bóg poprowadzi cię do ludzi, których będziesz mógł zaprowadzić do Chrystusa”. W ewangelii Jezus daje nam siebie. On jest rzeczywiście obecny w słowie Bożym: „albowiem gdy w Kościele czyta się Pismo święte, wówczas On sam mówi”" "Co więcej, jak napisał papież Paweł VI, Chrystus ,jest obecny w przepowiadaniu swojego Kościoła, ponieważ ewangelia opowiadana jest słowem Bożym i jedynie w imieniu i powagą Chrystusa, Słowa Wcielonego i przy Jego pomocy jest głoszona"14. Dlatego proklamowanie dobrej nowiny nie stanowi li tylko przekazu informacji, pewnej wiedzy na temat Jezusa i historii zbawienia. Tu chodzi o coś więcej - o udzielanie mocy, jaka tkwi w słowie Bożym. Słowa Pisma Świętego stanowią specyficzną formę realnej obecności Chrystusa. Kto potrafi przez wiarę dostrzec Go w tym słowie, nawiązuje z Nim zbawczy kontakt i przyjmuje Jego moc.

Nie może więc dziwić fakt, że zarówno II Sobór Watykański jak i późniejsze nauczanie Kościoła uznaje priorytet przepowiadania słowa Bożego w posłudze biskupów i kapłanów ${ }^{15}$. Wypowiedź ta nie oznacza deprecjonowania roli Eucharystii w życiu i posłudze kapłanów, a jedynie podkreśla pewną logikę chronologiczną. Zanim ktoś przystąpi do sakramentów, musi uwierzyć, a wiara rodzi się ze słuchania słowa Bożego. Karmienie się słowem uprzedza chronologicznie karmienie się Eucharystią, stąd jego priorytet w porządku czasowym. Natomiast w porządku hierarchicznym pierwszeństwo należy do Eucharystii, która - dzięki substancjalnej obecności Chrystusa - jest szczytem i źródłem życia Kościoła ${ }^{16}$. Zanim jednak ktoś wstąpi na szczyt, musi poznać smak wspinaczki, jaką jest wiara. Ona zaś, by zaistnieć, potrzebuje słowa Bożego.

Najskuteczniejsza proklamacja słowa Bożego ma miejsce wówczas, gdy jest potwierdzona życiem głoszącego, bo „człowiek naszych czasów chętniej słucha świadków, aniżeli nauczycieli; a jeśli słucha nauczycieli, to dlatego,

${ }^{12}$ Por. EE 44.

${ }^{13} \mathrm{KL} 7$.

${ }^{14}$ PAwel VI, Mysterium fidei (5 września 1965), 36. To sformułowanie Pawła VI zostało powtórzone we Wprowadzeniu teologiczno-pastoralnym do Lekcjonarza mszalnego z 1981 roku, nr 24.

${ }^{15}$ Por. DB 12; DK 4.

${ }^{16}$ „Z duszpasterskiego punktu widzenia pierwsze miejsce w porządku działania przysługuje przepowiadaniu. W porządku zamierzenia lub celowości pierwsze miejsce należy przyznać sprawowaniu sakramentów, zwłaszcza pokuty i Eucharystii" - KonGREGACJA DO SPRAW DuchowIEŃSTwA, Kapłan głosiciel słowa, szafarz sakramentów i przewodnik wspólnoty w drodze do trzeciego tysiąclecia chrześcijaństwa, Tarnów 1999, s. 22. 
że są świadkami”"17. To najistotniejsze, a zarazem najtrudniejsze zadanie: prezentować wyrazisty, czytelny obraz kapłaństwa i chrześcijaństwa. Bardziej przekonujący dzisiaj są świadkowie niż nauczyciele. Bardziej fascynuje dowódca, który woła: „Żołnierze, za mną”, aniżeli ten, który wydaje rozkaz: „Żołnierze, naprzód”. Najskuteczniejszymi kaznodziejami nie są ci, którzy opanowali zasady retoryki i posiedli wszechstronną wiedzę, ale ci, którzy życiem świadczą o prawdziwości ewangelii. Wyraziste, osobiste i wspólnotowe świadectwo nowego życia w Chrystusie stanowi istotny warunek wstępny autentycznej ewangelizacji. „Nie wystarcza bowiem przekazywać prawdę i łaskę przez głoszenie Słowa i sprawowanie sakramentów; konieczne jest, by były one przyjmowane i przeżywane w każdej konkretnej sytuacji, w sposobie życia chrześcijan i wspólnot kościelnych. Jest to jedno z największych wyzwań, jakie stają przed Kościołem w Europie na początku nowego tysiąclecia"18.

Oprócz świadectwa życia konieczna jest niezłomna wierność ewangelii, a to oznacza koncentrację przepowiadania kościelnego we wszystkich jego formach na osobie Jezusa. Całościowe, wyraźne i odnowione głoszenie Jezusa Chrystusa nie tylko jako wzorca etycznego, ale przede wszystkim jako Syna Bożego, jedynego Zbawcy, który żyje i działa w swoim Kościele stanowi - według Jana Pawła II - priorytet działalności duszpasterskiej najbliższych lat ${ }^{19}$.

Z pomocą łaski Bożej słowa ewangelii mają moc przeobrażania ludzkich serc, dlatego ogłoszony rok Eucharystii i kult eucharystyczny nie może zastąpić priorytetowej posługi przepowiadania Chrystusa. Proklamacja słowa Bożego pozostaje zawsze pierwszym i niezbędnym środkiem ewangelizacji. „Wiemy, że dzisiaj ludzie są już przesyceni mowami, bardzo często znudzeni słuchaniem, a co gorsza, nieczuli na słowa. Znamy też zdania wielu psychologów i socjologów, którzy utrzymują, że cywilizacja słowa, jako nieskuteczna i nieużyteczna, już się przeżyła, a obecnie następuje nowy styl życia, cywilizacja obrazu [...]. A niechęć, wywołana dziś nadmiarem pustych mów, i aktualność całkiem innych form przekazu społecznego nie powinna osłabiać mocy słów, ani odebrać im zaufania. Słowo zawsze posiada swą wyższość i skuteczność, zwłaszcza gdy niesie z sobą moc Bożą (por. 1 Kor 2, 1-5). Z tego powodu i w naszych czasach zachowuje swą aktualność Pawłowe: «Wiara ze słuchania» (Rz 10, 17): słowo usłyszane prowadzi do wierzenia"20.

Nie ma przepowiadania słowa Bożego bez pomocy Ducha Świętego. On działa zarówno w głosicielu ewangelii, który poddaje się Jego kierownictwu,

\footnotetext{
${ }^{17}$ PAWet VI, Evangelii nuntiandi (8 grudnia 1975), 41.

${ }^{18}$ EE 49.

${ }^{19}$ Por. EE 48.

${ }^{20}$ PAwet VI, Evangelii nuntiandi, 42.
} 
jak też w słuchaczach, usposabiając ich do przyjęcia i rozumienia głoszonego słowa $^{21}$. Oprócz całkowitego zawierzenia Duchowi Świętemu, niezbędne jest ze strony kaznodziei oparcie przepowiadania na solidnych argumentach. Bywały w przeszłości okresy, w których przeceniano apologetykę, czyli chęć przekazywania dobrej nowiny za pomocą samego tylko rozumu, bez odwołania do serca: do woli i uczuć. Dziś jednak dostrzega się niedostatek argumentacji rozumowej, a przecież dojrzała wiara szuka zrozumienia ${ }^{22}$.

\section{Ewangelia nadziei wobec mrocznych stron życia}

W czym upatrywać słabości naszego przepowiadania słowa Bożego? $\mathrm{Z}$ pewnością nie w braku ortodoksyjności. Zarówno niedzielne homilie, jak i katechezy głoszone są w Polsce w duchu nauczania Kościoła. Problem tkwi nie tyle w wierności Bogu, co w wierności człowiekowi. Niekiedy może być potrzebny lament kaznodziei, bunt wobec cierpienia i zła, które dotyka ludzi. Jednak nawet z głębi bólu musi wyłonić się orędzie dobrej nowiny. Bywają sytuacje, których kaznodzieja nie jest w stanie zmienić. Nie wskrzesi zmarłych, nie zatrzyma inflacji ani nie obniży bezrobocia. Może jednak pomóc słuchaczom w uchwyceniu związku pomiędzy rzeczywistością ich życia i rzeczywistością ewangelii. Można wskazać, jak Bóg w Jezusie Chrystusie wszedł w ludzką rzeczywistość bólu i szczęścia i zidentyfikował się z nami ${ }^{23}$. To jest ewangelia nadziei. Jej głoszenie wymaga od kaznodziejów „spostrzegawczego oka” i „uważnego ucha”, tj. wrażliwości na problemy słuchaczy. Należałoby więc najpierw przyjrzeć się złej nowinie, czyli doświadczeniu pozornej nieobecności Boga, albo przynajmniej rozważyć, że Bóg nie proponuje łatwych rozwiązań naszych problemów ${ }^{24}$. Głoszenie ewangelii nadziei nie może być powierzchowne. Bóg jest bowiem często doświadczany jako nieobecny. Zarówno katoliccy, jak i protestanccy homileci przestrzegają przed pośpiesznym zwiastowaniem dobrej nowiny, zanim nie zostanie wpierw należycie podjęta ciemna strona rzeczywistości, na którą składają się wszelkie niewierności, niesprawiedliwość, gwałt, kłamstwa ${ }^{25}$. Zanim zaproponujemy naszym słuchaczom wizję raju, nie powinniśmy uchylać się przed odmalowaniem pełnej panoramy ludzkiej pustyni $^{26}$. Głoszenie dobrej nowiny, przy zignorowaniu złej nowiny, byłoby iluzją. Jednak większym zagrożeniem dla przepowiadania jest koncentracja na złu

${ }^{21}$ Por. Pawet VI, Evangelii nuntiandi, 75.

${ }^{22}$ Por. G. Danneels, Jak ewangelizować „zsekularyzowana” Europę?, art. cyt., s. 13.

${ }^{23}$ Por. FIYH, s. 10.

${ }^{24}$ Por. W. A. Richard, Preaching the Dark Side of the Gospel, „Worship” 61 (1987) nr 2, 141 (141-151).

${ }^{25}$ Por. W. A. Richard, Preaching the Dark Side of the Gospel, art. cyt., s. 144-147; F. B. Craddock, Overhearing the Gospel, Nashville 1978, s. 138. 
w świecie i bezowocne malkontenctwo. Tego rodzaju głoszenie straciłoby znamiona proklamacji dobrej nowiny. Byłoby pozbawione nadziei, a więc stałoby się po prostu przepowiadaniem beznadziejnym. Kaznodzieje stają przed takim samym wyzwaniem, z jakim zmagali się prorocy i poeci: kreślić nowe możliwości, widzieć w ciemnościach. Np. Etty Hillesum, holenderska Żydówka, która zginęła w Oświęcimiu w listopadzie roku 1943, potrafiła nawet w piekle obozu zagłady zachwycać się pięknem jaśminu ${ }^{27}$. Krzysztof Kolumb odkrył Amerykę, bo dziadek zaszczepił w jego młodzieńczym sercu przekonanie, że za bezmiarem fal znajduje się nieznany ląd.

Proklamacja ewangelii nadziei powinna odznaczać się tą samą właściwością, co opowiadania biblijne, które zachowują aktualność, ponieważ są wystarczająco podobne do naszego życia, przez co umożliwiają słuchaczom identyfikację, a jednocześnie są dość różne od naszego życia, a przez to pozwalają dostrzec nowe możliwości ${ }^{28}$. Jedynie dotknięcie ciemnych strony życia stwarza miejsce dla nadziei. Oderwanie od realiów życiowych byłoby „opium dla ludu”, utopią, a nie nadzieją. Tymczasem orędzie ewangelii nadziei nie proponuje apatycznej bezczynności, pasywnej postawy wobec codzienności, lecz wręcz przeciwnie, daje siłę do odnowy naszego niedoskonałego bytu w świecie; skłania do przechodzenia od tego, co jest, do tego, co - dzięki wielorakiej łasce Bożej - może się stać. Wytrąca ze świętego spokoju i burzy stoicką akceptację status quo. Jest obce marazmowi, bo kierując wzrok ku temu, co możliwe, skłania do przeobrażania teraźniejszości. Dlatego nawet świadomość, że dziś lub jutro może nastąpić koniec świata, nie przeszkadza pracować do ostatniego momentu. II Sobór Watykański zawarł bowiem nader wyraźną przestrogę: „Chrześcijanin, zaniedbujący swoje obowiązki doczesne, zaniedbuje swoje obowiązki wobec bliźniego, co więcej, wobec samego Boga i naraża na niebezpieczeństwo swoje zbawienia wieczne"29. Ewangelia nadziei, podsuwając nową wizję porządku społecznego, niesie w sobie przedziwną moc, a w niektórych wypadkach staje się wręcz niebezpieczna dla istniejącego establishmentu. Amerykanie doświadczyli tej mocy wówczas, gdy Martin Luther King Jr., wygłosił kazanie Miałem sen, którym poruszył cały naród ${ }^{30}$. Podobnie oddziaływał

${ }^{26}$ „Do not be afraid to paint vividly the full panorama of the human desert before presenting the congregation with a vision of Eden" - W. A. RICHARD, Preaching the Dark Side of the Gospel, art. cyt., s. 147.

${ }^{27}$ Zob. Etty Hillesum, Przerwane życie. Pamiętnik 1941-1943, Kraków 2000; Myślace serce. Listy Etty Hillesum, Kraków 2002.

${ }^{28}$ Por. J. SHEA, Stories of Faith, Chicago 1980, s. 114; por. R. P. WAZnAK, The Preacher..., art. cyt., s. 54.

${ }^{29}$ KDK 43.

${ }^{30}$ Por. R. P. WAZnAK, The Preacher..., art. cyt., s. 54. 
na naród arcybiskup Salwadoru Oscar Arnulfo Romero (1917-1980). Był głosem pozbawionych głosu. Bronił praw ludzkich i kreślił wizję reformy rolnej oraz sprawiedliwości społecznej. Został zastrzelony 24 marca 1980 roku tuż po wygłoszeniu homilii na temat ziarna, które wpada w ziemię i musi umrzeć, aby wydać plon obfity. Głosił ewangelię nadziei jak prorok i spotkał go los proroka. To samo można powiedzieć o księdzu Jerzym Popiełuszce. Dotykał newralgicznych bólów społeczeństwa. Przepowiadanie osadzone głęboko w realiach codziennego życia jest ryzykownym przedsięwzięciem, nie jest ono jednak alternatywą, ale koniecznością. Jeśli bowiem kaznodzieja głosi bardzo uniwersalne kazanie, skierowane do wszystkich, aktualne w każdym czasie, to należy przypuszczać, iż jest to bardzo słabe przepowiadanie. II Sobór Watykański zauważył bowiem, że jeśli posługa słowa ma poruszyć umysły słuchaczy, nie może sprowadzać się do ogólnych i abstrakcyjnych stwierdzeń, lecz winna dostosować odwieczną prawdę ewangelii do konkretnych warunków życia ${ }^{31}$. Musi posiadać pewien koloryt lokalny - mówimy wówczas o aktualizacji ewangelii.

Ewangeliczne przesłanie nadziei nie jest więc ucieczką od rzeczywistości, ale umocnieniem przeciw wszelkim przeszkodom i trudnościom życiowym. Jezus uczy, że prawdziwy sens życia człowieka nie jest ograniczony horyzontem doczesności, ale ma przed sobą wieczność32 ${ }^{32}$ Również Kościół nie przestaje pokazywać z jednej strony szczęśliwej wieczności, otwartej dla człowieka, a z drugiej - doniosłości zadań ziemskich, których nadzieja eschatologiczna nie pomniejsza, lecz wspiera ich spełnianie religijnymi pobudkami. Fascynacja nadzieją eschatologiczną nie koliduje z akceptacją doczesnych wyzwań. Wymowne jest pod tym względem wyznanie Jana Pawła II: „Mimo ograniczeń mego wieku bardzo wysoko cenię sobie życie i umiem się nim cieszyć. Dziękuję za to Bogu! Pięknie jest służyć aż do końca sprawie Królestwa Bożego. Zarazem jednak głębokim pokojem napełnia mnie myśl o chwili, w której Bóg wezwie mnie do siebie z życia do życia! Dlatego wypowiadam często i bez najmniejszego odcienia smutku modlitwę, którą kapłan odmawia po liturgii eucharystycznej: w godzinie śmierci wezwij mnie i każ mi przyjść do siebie. Jest to modlitwa chrześcijańskiej nadziei, która w niczym nie umniejsza radości obecnej chwili, a przyszłość zawierza opiece Bożej dobroci"33.

Nie deprecjonując rzeczywistości ziemskiej, ewangelia nadziei pomaga nabrać właściwego dystansu do doczesności. Brak owego dystansu, wskutek

\footnotetext{
${ }^{31}$ Por. DK 4.

${ }^{32}$ Por. EE 21.

${ }^{33}$ JAN PAWEŁ II, List do ludzi w podeszłym wieku (1 października 1999), 17.
} 
zapomnienia o transcendentnym wymiarze ludzkiego powołania, pozostawia pustą przestrzeń dla „rozwoju nihilizmu na polu filozofii, relatywizmu na polu teorii poznania i moralności, pragmatyzmu i nawet cynicznego hedonizmu w strukturze życia codziennego" ${ }^{34}$. Postawy takie nader często owocują zagubieniem sensu życia i powodują poważny uszczerbek godności człowieka, a najistotniejsze pytania dotyczące życia i śmierci, winy i cierpienia pozostają bez odpowiedzi, tak że ludzie nierzadko popadają w rozpacz ${ }^{35}$. Rozpacz zaś jest przeciwieństwem nadziei, jest piekielnym dramatem. W Boskiej komedii Dantego nad bramą piekła widnieje napis: „Porzućcie wszelką nadzieję wy, którzy tu wchodzicie". Piekło jest wiecznością, w której nie ma już szansy na zmianę. Związana z nim rozpacz polega na zamknięciu się człowieka w sobie i ograniczeniu horyzontu swego bytowania. Ratunkiem i ocaleniem od rozpaczy jest wejście człowieka w osobowe relacje z drugim człowiekiem i z Bogiem. Dlatego ratunkiem dla człowieka i społeczeństwa zagrożonego rozpaczą jest ewangelia nadziei, broniąca godności człowieka i kojąca najtajniejsze pragnienia ludzkiego serca, które wyraził św. Augustyn: „Jakże wielki jesteś, Panie, i godny, by Cię sławić [...]. Stworzyłeś nas bowiem dla siebie i niespokojne jest nasze serce, dopóki nie spocznie w Tobie"36. Człowiek nie może żyć bez nadziei; nie może żyć bez perspektyw na przyszłość: jego życie straciłoby bez niej wszelkie znaczenie i stałoby się nie do zniesienia ${ }^{37}$. Nadzieja otwiera przed człowiekiem i społeczeństwem horyzonty rozwoju, dzięki temu człowiek i społeczeństwo są gotowi do działania. Historia ludzkości (a szczególnie historia odkryć naukowych) pokazuje, iż były one możliwe dzięki nadziei. Nadzieja dynamizuje. Ma w sobie coś z Ducha Bożego; jest cnotą boską.

\section{Pasja głoszenia ewangelii nadziei}

Nie można przepowiadać skutecznie bez nadziei i bez pasji. Głosiciel słowa Bożego musi być rozpalony przez to, co głosi. Do proklamacji ewangelii nadziei potrzebni są kaznodzieje i katecheci, którzy przypominają sparaliżowanego dziadka z opowieści hasydzkiej Martina Bubera: „Mój dziadek był sparaliżowany. Pewnego dnia poproszono go, aby opowiedział coś z życia swego nauczyciela - wielkiego Baal Szem Tow. Dziadek opowiedział, jak Baal Szem Tow zwykł podskakiwać i tańczyć podczas modlitwy. Wypowiadając te słowa, mój dziadek powstał z miejsca; opowiadanie tak go poniosło, że sam zaczął podskakiwać i tańczyć, aby pokazać, w jaki sposób

\footnotetext{
${ }^{34}$ EE 9.

${ }^{35}$ Por. KDK 21.

${ }^{36}$ Św. Augustyn, Wyznania, I, 1, 1; por. KDK 21; KKK 30.

${ }^{37}$ Por. EE 10.
} 
czynił to jego mistrz. Od tego momentu był uzdrowiony. Oto, jak należy przekazywać opowiadania"38. Jeden z sekretów skutecznego przepowiadania tkwi właśnie w pasji, w entuzjazmie.

Jeśli głosiciele ewangelii będą pamiętać o tym, jaka jest etymologia tego słowa, nie ograniczą się do piętnowania wad współczesnego społeczeństwa europejskiego. Będą raczej jak prorocy i poeci kreślić nowe wizje. Będą zapalać innych, pokazywać nowe możliwości. Chrześcijańskie przepowiadania jest zawsze dobrą nowiną. Jego sens tkwi w rozpalaniu światła, a nie w przeklinaniu ciemności.

Przechodząc przez Drzwi Święte na początku roku jubileuszowego 2000, Jan Paweł II zademonstrował Kościołowi i światu księgę Ewangelii. Ten gest, powtórzony przez wszystkich biskupów świata w ich katedrach, wskazał zadanie, jakie stoi przed Kościołem w Europie i na świecie. Kościół wchodzi w nowe tysiąclecie z księgą Ewangelii, przypominając swoim wiernym soborową zachętę, „aby przez częste czytanie pism Bożych osiągali «najwyższą wartość poznania Jezusa Chrystusa» (Flp 3, 8): «Nieznajomość Pisma świętego jest bowiem nieznajomością Chrystusa»"39. Papież zachęca, abyśmy na nowo rozpalili w sobie miłość do słowa Bożego i połykali je (por. Ap 10, 9). W nim bowiem znajdziemy pokarm i moc, by wypełniać codziennie swą zaszczytną misję przepowiadania ewangelii nadziei ${ }^{40}$. Rok Eucharystii nie powinien przesłonić prawdy o potrzebie proklamacji ewangelii nadziei. Co więcej, może posłużyć rozbudzeniu świadomości, że prawdziwa pobożność eucharystyczna jest owocem przyjęcia przez wiarę Chrystusa rzeczywiście obecnego w słowie Bożym i w liturgii świata. Choć czasem wydaje się, że Chrystus jest nieobecny, albo przynajmniej śpi, pozostawiając łódź Kościoła na pastwę wzburzonych fal (por. Mk 4, 35-41; Łk 8, 22-25), doświadczenie wiary dwu tysięcy lat Kościoła w Europie daje pewność, że „Pan - poprzez dar swego Ducha - jest zawsze obecny i działa w nim i w historii ludzkości”41.

Od niemal dwóch tysięcy lat głoszona jest dobra nowina Jezusa Chrystusa. Jej niezmienne orędzie stanowi życiową siłę i źródło nadziei dla wszystkich, którzy przyjmują ją z wiarą. Aktualność tego orędzia wynika z faktu, że dotyczy ono newralgicznych pytań, jakie człowiek stawia sobie

${ }^{38}$ M. Buber, Werke, Band 3, München 1963, s. 71; por. M. C. HiLkert, Naming Grace. A Theology of Proclamation, „Worship” 60 (1986) nr 5, s. 448-449.

${ }^{39} \mathrm{KO} 25$.

${ }^{40}$ Por. EE 65.

${ }^{41}$ EE 27. 
od zarania dziejów. Odpowiedź ewangelii na te pytania jest bliska ludzkim problemom i konkretna, jak krew Jezusa przelana na krzyżu, a jednocześnie pełna nadziei, jak przesłanie wielkanocnego poranka.

Kraków

KS. HENRYK SEAWIŃSKI

\section{Summary}

Preaching the Gospel of Hope in the light of the apostolic exhortation „Ecclesia in Europa”

The article deals with the preaching of hope, taking into consideration the apostolic exhortation of John Paul II, Ecclesia in Europa. The main reasons of the spiritual crisis in Europe and the loss of hope among it's inhabitants might be seen in: living as if God does not exist, hedonism and consumerism. In consequence a man more fears the future then desires it. In this situation the Church is being urged to fulfil her joyful duty of preaching the gospel of hope, i.e. Jesus Christ the Lord. He is the hope for the whole world. He allows the discovery of the truth and gives the ultimate reason for life worth living. The church gives witness of its hope in Jesus Christ. The preaching of the Church is to be understood not only as the deliverance of some religious information, but as the power of God, because Christ is present in his word and in the Church's preaching. From a pastoral perspective, preaching is to be considered the primary action of the church, whereas from the perspective of intentionality, the primary element of the church's activity must be the celebration of the sacraments. The weakness of our preaching lays not in the lack of the orthodoxy, but in too weak an emphasis of the positive aspects of the proclamation of the gospel. The most extensive danger for preaching is the concentration on evil in the world and the fruitless abomination. Only the preaching born with hope may set the preacher and his listeners on fire. Preaching of hope has in itself something from the Holy Spirit, it is dynamic and shows that Jesus is present in his Church and in the history of human beings, although it may seem otherwise, that $\mathrm{He}$ is not present or asleep, leaving the boat of the Church to the power of the wrath of the waves. 